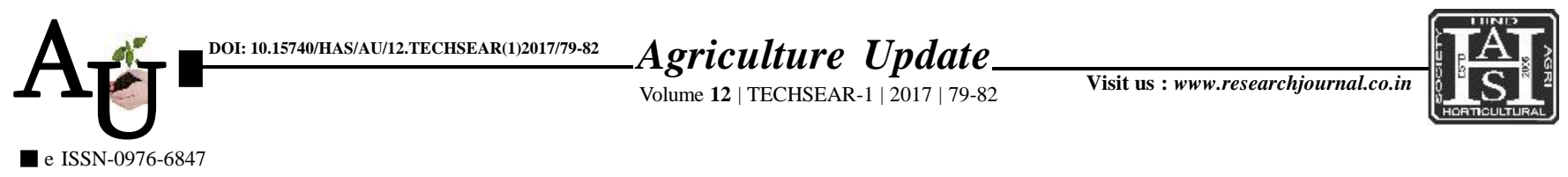

\title{
Rевавсн автіске: Utilization and identification of rice genetic stock against false smut disease under agro conditions of Jabalpur (M.P.)
}

\author{
DEVENDHAR VAKITI, USHA BHALE, T. RAMYA TEJA, M.S. BHALE AND \\ G.K. KOUTU
}

Article Chronicle: Received : 05.07.2017;

Accepted : 22.07.2017

KeY Words: False smut, Rice, Evaluation of varieties, Hybrids, NPT lines
SUMMARY : Rice (Oryza sativa L.) is the most important cereal food crop and the primary source of livelihood for about half of the global population. With the changing climatic variations the proneness of the crop is also experienced. One time considered as minor problem, are being observed as a severe and wide spread threats. False smut (Ustilaginoidea virens) has emerged as an alarming malady primarily due to change in weather conditions, increased applications of nitrogenous fertilizers and large scale cultivation of the crop. Disease appears at grain filling stage and in a panicle few grains turned into smut balls of the fungus. Later at pre harvest and threshing stage, smut balls are ruptured and spores are spread out and sticks to the new grains, that helps in seed associated dissemination. Spore balls also fall down and contaminate the soil that serves as secondary source of inoculum. Considering the crop improvement as an effective and cheaper means to combat the problem, evaluation of genetic pool was under taken in naturally infected soil conditionsat JNKVV, Jabalpur (M.P.). It was observed that among 40 rice varieties, seven exhibited no incidence of false smut, while only three rice hybrids were free from infection out of 19 hybrids. Out of 120 JNPT lines 82 were free and had no disease whereas 15 land races were identified no incidence out of 25 land races tested. Among $15 \mathrm{~A}$ lines, four lines did not exhibit the association of false smut.At JNKVV, Jabalpur these identified lines are being used for crop improvement and as a result Jawahar Hybrid Rice 76, JRH 85 have been developed for release.

How to cite this article : Vakiti, Devendhar, Bhale, Usha, Teja, T. Ramya, Bhale, M.S. and Koutu, G.K. (2017). Utilization and identification of rice genetic stock against false smut disease under agro conditions of Jabalpur (M.P.). Agric. Update, 12(TECHSEAR-1) : 79-82; DOI: 10.15740/HAS/AU/12.TECHSEAR(1)2017/79-82.
Author for correspondence :

\section{DEVENDHAR VAKITI}

College of Agriculture, Jawaharlal Nehru Krishi Viswa Vidyalaya, JABALPUR (M.P.) INDIA Email:vakiti.devendhar@ gmail.com

See end of the article for authors' affiliations 